\title{
French and Swiss banks as initiators of implementation and use of Crowdfunding Systems \\ Dariusz T. Dziuba
}

Full Professor, Faculty of Economics, University of Warsaw, Długa St. 44/50, 00-241 Warszawa, Poland.

Email: dziubadt@wne.uw.edu.pl

\begin{abstract}
Keywords
Crowdfunding, Electronic Platforms,

Banks in France and Switzerland,

Corporate Social Responsibility.

Article History

Received on $27^{\text {th }}$ October 2021

Accepted on $17^{\text {th }}$ January 2022

Published on $25^{\text {th }}$ January 2022

Cite this article

Dziuba, D. T. (2022). French and Swiss

banks as initiators of implementation and use of Crowdfunding Systems.

Humanities \& Social Sciences Reviews,

10(1), 08-16.

https://doi.org/10.18510/hssr.2022.1012
\end{abstract}

Copyright @Author

Publishing License

This work is licensed under a Creative Commons Attribution-Share Alike 4.0 International License

(c)

\section{Abstract}

Purpose of the Study: The subjects of the considerations are initiatives to implement or use the method of online crowdfunding by banks. The focus was on such implementations in France and Switzerland, i.e. countries with a relatively large number of such projects. The presented research identifies crowdfunding platforms and (depending on access to data) determines the size in terms of value of the analyzed market sub-segment and its specificity. This work is a continuation of a series of author's publications aimed at examining the crowdfunding market sub-segment of banks in Europe.

Methodology: Crowdfunding platforms in individual French and Swiss banks were identified. Data was obtained from internet resources, supported by, inter alia, available publications. The final data was obtained directly from the websites of the analyzed financial institutions (or platforms), or they were aggregated, or the data was estimated on the basis of partial information. The research was carried out in October and November 2021, with data verification as of November 30.

Main Findings: The article explores a specific market segment in France and Switzerland - banks implementing or using crowdfunding platforms. The scope of implementation of such systems was determined by identifying the individual analyzed financial institutions. The value of accumulated financial resources (capital) and the scope of project implementation were measured, distinguishing the size of the market sub-segment under study. The examined systems collectively obtained a relatively large amount, over EUR 4326 million.

Applications of the Study: The presented article concerns the applications of the crowdfunding method in financial institutions (French and Swiss banks). This implies considerations in several scientific fields, incl. economics (the possibility of measuring the market segment), business informatics (electronic platforms; human-computer interactions).

Novelty / Originality of this Study: The scientific literature on the use of crowdfunding in banks, and especially the measurement of the size of this market segment, is almost non-existent, it is only fragmentary. The separation in this article of the size of the crowdfunding sub-segment in French and Swiss banks, although partial, seems prospective, as it allows for further research in this area. 


\title{
Banki francuskie i szwajcarskie jako inicjatorzy wdrażania, I wykorzystywania systemów crowdfundingu
}

\author{
Dariusz T. Dziuba
}

Prof. dr hab., Wydział Nauk Ekonomicznych, Uniwersytet Warszawski, Długa 44/50, 00-241 Warszawa, Polska. Email: dziubadt@wne.uw.edu.pl

\section{Słowa kluczowe}

Zwinne Zarządzanie, Zwinna

Organizacja, Zwinność Pracownicza,

Zarządzanie Ryzykiem.

Historia artykułu

Otrzymano 27 październik 2021

Przyjęta 17 Styczeń 2021

Opublikowane 25 Styczeń 2021

Cite this article

Dziuba, D. T. (2022). French and Swiss

banks as initiators of implementation

and use of Crowdfunding Systems.

Humanities \& Social Sciences Reviews,

10(1), 08-16.

https://doi.org/10.18510/hssr.2022.1012

Copyright @Author

Publishing License

This work is licensed under a Creative Commons Attribution-Share Alike 4.0 International License

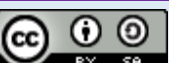

\section{Streszczenie}

Cel badawczy: Przedmiotem rozważań są inicjatywy wdrażania bądź wykorzystywania metody crowdfundingu internetowego przez banki. Skoncentrowano się na implementacjach we Francji i Szwajcarii, tj. krajach o relatywnie dużej liczbie takich przedsięwzięć w Europie. Prezentowane badania identyfikują platformy crowdfundingu oraz (w miarę dostępu do danych) określają rozmiary w kategoriach wartościowych analizowanego sub-segmentu rynkowego i jego specyfikę. Artykuł jest kontynuacją serii autorskich publikacji oceniających wykorzystywanie systemów crowdfundingu w bankach krajów europejskich.

Metoda badawcza: Dokonano identyfikacji platform crowdfundingu w poszczególnych bankach Francji i Szwajcarii. Dane pozyskiwano z zasobów internetowych, wspomagając się m.in. dostępnymi publikacjami. Finalne dane czerpano bezpośrednio ze stron Web analizowanych instytucji finansowych (albo platform), bądź dokonywano ich agregacji, albo też dane szacowano na podstawie cząstkowych informacji. Badań dokonano w miesiącach październik i listopad 2021 roku, z weryfikacją danych według stanu na dzień 30 listopada.

Uzyskane wyniki: W artykule udało się zbadać specyficzny segment rynkowy w Szwajcarii i we Francji - banki, wdrażające bądź wykorzystujące platformy crowdfundingu. Określono zakres implementacji takich systemów identyfikując poszczególne analizowane instytucje finansowe. Dokonano pomiaru wartości gromadzonych środków finansowych (kapitału) i zakresu realizacji projektów, wydzielając rozmiary badanego sub-segmentu rynkowego. Badane systemy łącznie pozyskały relatywnie dużą kwotę, ponad 4326 milionów euro.

Zastosowania tych badań: Prezentowany artykuł dotyczy zastosowań metody crowdfundingu w instytucjach finansowych (bankach francuskich i szwajcarskich). Implikuje to przemyślenia w kilku dziedzinach naukowych, m.in. ekonomii (możliwości pomiaru segmentu rynkowego), informatyki ekonomicznej (elektroniczne platformy; interakcje człowiek-komputer).

Oryginalność tych badań: Literatura naukowa na temat zastosowań crowdfundingu w bankach, a zwłaszcza pomiaru rozmiarów tego segmentu rynkowego niemalże nie istnieje, jest jedynie fragmentaryczna. Wydzielenie w niniejszym artykule rozmiarów sub-segmentu crowdfundingu we francuskich i szwajcarskich bankach, choć cząstkowe, wydaje się perspektywiczne, gdyż daje możliwość realizowania dalszych badań w tym zakresie.

\section{WSTĘP}

Niniejsza praca jest kontynuacją cyklu autorskich publikacji, których celem jest wydzielenie i zbadanie sub-segmentu rynkowego crowdfundingu w bankach europejskich. W artykule na łamach "Humanities and Social Sciences Reviews" (Dziuba, 2021a) oceniano zakres wdrożeń w niemieckich kasach oszczędnościowych i bankach Volks- Raiffeisen. W tym opracowaniu koncentrujemy się na implementacjach w bankach Francji i Szwajcarii, tj. krajów o relatywnie wysokiej liczbie takich przedsięwzięć w Europie.

Celem badań jest uzyskanie odpowiedzi na pytanie: jakie są rozmiary w kategoriach wartościowych i ilościowych analizowanego sub-segmentu rynkowego oraz jego specyfika. Uzupełniająco poszukiwano odpowiedzi na następujące pytania: jaki jest zakres wdrożeń i wykorzystania systemów crowdfundingu w analizowanych krajach; ile w ten sposób zgromadzono środków finansowych na sfinalizowane projekty; jakie strategie biznesowe realizują banki w zakresie wdrażania (wykorzystywania) platform crowdfundingu.

W kolejnych rozważaniach zaprezentowano: przegląd literatury w zakresie crowdfundingu; proponowaną metodę badawczą (wraz z jej ograniczeniami); specyfikę partnerstwa banków i platform crowdfundingu; ocenę sub-segmentu crowdfundingu $\mathrm{w}$ bankach Francji; wyodrębnienie i pomiar rozwoju crowdfundingu w szwajcarskich bankach, w szczególności kantonalnych i grupy Raiffeisen; rekapitulacji rozważań i identyfikacji strategii (modeli biznesowych) banków dokonano w podsumowaniu. 


\section{KONCEPCJA CROWDFUNDINGU - PRZEGLĄD LITERATURY}

Szerokiego przeglądu literatury światowej z zakresu crowdfundingu dokonano m.in. w pracy (Dziuba, 2021a), odsyłając do publikacji takich autorów jak A. Agrawal, Ch. Catalini, A. Goldfarb, E.R. Mollick, R. Belleflamme, T.Lambert, A. Schwienbacher. Tu skoncentrujemy się jedynie na wybranych zagadnieniach.

Liczne definicje (Humphries, 2020), (Dresler, 2014), (Danmayr, 2014), (Rich, 2014) uwypuklają, że crowdfunding (internetowy) to metoda gromadzenia środków finansowych na projekty lub przedsięwzięcia od dużej grupy osób. Jenik et.al. (2017: vii) z kolei wskazują, że jest to metoda finansowania, w której małe kwoty pieniędzy są pozyskiwane od ogromnej liczby jednostek bądź organizacji, na potrzeby fundowania biznesów, specyficznych projektów, konsumpcji indywidualnej, albo innych celów; skutkuje to pomijaniem ,tradycyjnych” pośredników rynkowych (np. banków) i wykorzystywaniem platform elektronicznych w środowisku Web. W zbliżony sposób (w węższym ujęciu) określa crowdfunding Burkett: to proces, w którym np. przedsiębiorcy, artyści itp. zbierają środki finansowe na potrzeby ich projektów, przedsięwzięć, bazując na wsparciu wielu osób, które wspólnie ofiarowują pieniądze na takie projekty, przedsięwzięcia itp., bądź inwestują w nie. Por. (Burkett, 2011: 66). Definicje crowdfundingu różnią się, choć obejmują zwykle kilka kluczowych elementów: (a) gromadzenie środków finansowych w jednostkowych, małych kwotach; (b) od wielu osób dla wielu; (c) bazowanie na technologiach cyfrowych (Ibidem). Crowdfunding jest zatem wielowymiarowym fenomenem; istota koncepcji wyrasta z wykorzystania technologii (zwłaszcza Internatu), co tworzy relacje między inwestorami (tj. stroną popytową) a przedsiębiorcami, tzn. stroną podażową (Brown, et.al., 2015: 6).

W praktyce spotykamy różne modele crowdfundingu. Najbardziej rozpowszechniony jest model donacyjny (crowddonating), w którym organizowana jest zbiórka środków finansowych na określony, np. filantropijny cel. W wersji modelu donacyjnego bez nagradzania ofiarodawcy nie oczekują świadczeń zwrotnych za okazane wsparcie, jak na platformie Philanthroper.org. Modyfikacją jest model z gratyfikowaniem niefinansowym uczestników, zwany sponsorskim (crowdsupporting) - tak funkcjonuje platforma Kickstarter.com). Darczyńcom oferowane są nagrody rzeczowe, np. bilety na imprezy kulturalne, płyty DVD itp.

Model pożyczkowy (crowdlending) z kolei umożliwia pożyczanie środków finansowych. Mogą to być zarówno systemy bezpośrednich pożyczek społecznych, jak i mikrokredytów. Mikrokredyty to pomoc finansowa oferowana w niewielkich kwotach, np. po 25 USD, jak poprzez system Kiva.org. Z drugiej strony, pożyczki społeczne dotyczą relatywnie wyższych kwot: uczestnicy gromadzą wolne środki finansowe, a następnie są one pożyczane na określonych warunkach (przykład: Zopa.com). Inny model reprezentują platformy inwestycyjne (crowdinvesting), w których uczestnicy lokują wolne środki finansowe w danych projektach, w oczekiwaniu na korzyści finansowe. Między innymi jest tu wykorzystywany model inwestycyjny-akcyjny (equity-based), w którym uzyskuje się gratyfikacje w formie papierów wartościowych. Spośród innych rozwiązań spotyka się model umożliwiający wykup faktur (invoice trading) i innych zobowiązań firm, dla potrzeb ich dofinansowania. Wdrażane są też modele hybrydowe, integrujące dotychczasowe podejścia.

W literaturze zwykle się uznaje, że crowdfunding jest metodą gromadzenia kapitału alternatywną np. wobec banków, a z drugiej strony, od ok. 2011 roku obserwuje się intrygującą tendencję (Dziuba, 2021b): implementacje crowdfundingu . następują w skali globalnej również w bankach, co można potraktować jako paradoks (Dziuba, 2021a). Interesującym będzie zatem zbadanie zakresu wdrożeń i wykorzystywania tej metody w bankach. W literaturze przedmiotu występuje luka badawcza w tym zakresie.

\section{METODA BADAWCZA}

Bazując na zasobach internetowych i dostępnych publikacjach dokonano identyfikacji platform crowdfundingu wykorzystywanych przez banki - ze względów organizacyjnych skoncentrowano się na dwóch krajach, Francji i Szwajcarii. W miarę dostępu do danych oceniano wartości zagregowanych środków finansowych pozyskiwanych przez poszczególne systemy; statystyki zbiorcze (jeśli je publikowano) czerpano bezpośrednio z witryn Web, bądź dokonywano agregacji kwot dla sfinalizowanych projektów, albo dokonywano szacunków na podstawie cząstkowych informacji. W przypadku kwot dla banków szwajcarskich dokonywano przeliczeń kursów walutowych. Przedmiotem rozważań były dwie podstawowe grupy platform crowdfundingu: wewnętrzne, korporacyjne systemy bankowe, bądź zewnętrzne platformy wykorzystywane przez banki (do realizowania na nich własnych lub innych projektów).

W miarę dostępu do danych także rozpatrywano inicjatywy (współ-)finansowania innych projektów na innych platformach, w szczególności stałą współpracę z zewnętrznymi platformami, w tym wynikającą ze strategii społecznej odpowiedzialności biznesu (CSR, Corporate Social Responsibility). W rozważaniach nie rozpatrywano:

- doraźnych, jednostkowych przedsięwzięć o charakterze donacyjnym;

- inicjatyw, w których nie są przekazywane środki finansowe, a rzeczowe;

- emisji papierów wartościowych poprzez crowdfunding;

- kampanii na rynku kapitałowym z użyciem kryptowalut;

- systemów awizowanych do wdrożenia w przyszłości;

- także agregatorów projektów crowdfundingu. 
$\mathrm{Z}$ drugiej strony, brane były pod uwagę systemy „powielarne” typu white-label, tj. platformy crowdfundingu jako usługi Software-as-a-Service (SaaS). ${ }^{\mathrm{i}}$ Nie rozpatrywano systemów awizowanych do wdrożenia w przyszłości. Zatem w polu naszych zainteresowań znalazły się platformy crowdfundingu obecnie funkcjonujące, jak i archiwalne, już nie istniejące. Badań dokonano w październiku i listopadzie 2021 roku, z weryfikacją wszystkich danych na dzień 30 listopada.

Proponowana metoda badawcza umożliwia realizację postawionych celów, jednakże uzyskane dane odnoszą się jedynie do wyznaczonego punktu czasowego. $\mathrm{Z}$ drugiej strony - w dalszej perspektywie - stwarza to możliwość porównywania badań z innymi okresami czasu. Ponadto, uzyskiwanie statystyk zależne jest od dostępu do danych. Pewnym ograniczeniem w zakresie porównywalności badań są także (mogą być) zmiany kursów walutowych.

\section{PARTNERSTWO BANKóW Z PLATFORMAMI CROWDFUNDINGU - PRZYKLAD FRANCJI}

\section{„(...) sita dystrybucyjna banków jeszcze bardziej}

demokratyzuje finansowanie społecznościowe" ${ }^{\text {ii }}$

Przeprowadzone badania wskazują, że zarówno banki, jak i platformy crowdfundingu uzyskują korzyści z partnerstwa, w tym m.in. w ramach strategii CSR. Jak zauważa Nicolas Guillaume, założyciel Prêt PME, „Podejmujemy kroki w kierunku akceptacji crowdfundingu przez banki. Na poczatku platformy byly postrzegane jako bezpośredni konkurenci (...). Teraz banki zdaja sobie sprawę, że udziat w rynku nie jest bez znaczenia (...)". Jednakże duże banki raczej ostrożnie podchodzą do tej problematyki; przykładem jest Société Générale, traktując partnerstwo z systemem Spear jako „,metode finansowania komplementarna do pracy banku (...)” - m.in. zapewnia rzecznik banku (Chaptal, 2015).

S. Chaptal podaje przykłady innych banków - BNP Paribas, który współpracuje z platformami crowdfundingu tylko poprzez swoje spółki zależne (Hello Bank z Ulule oraz poprzez Atelier Paribas z WiSeed), także najbardziej „zaawansowanego" banku francuskiego w tym zakresie - Crédit Coopératif, który oferuje niemal wszystkie modele crowdfundingu - darowizn na platformach Agir \& Co oraz Arizuka, pożyczek w Lumo i inwestycji w start-upy w WiSeed - crowdfunding postrzegany jest tu jako „przedłużenie działalności bankowej”. Dla Erwana Audouita z zarządu banku, chodzi o ,robienie biznesu. Crédit Coopératif ma dla wszystkich podmiotów kompletna ofertę crowdfundingu: pożyczki, darowizny i kapitat własny. (...) Celem pozostaje pozyskanie nowych klientów. (...). 70\% klientów Agir \& Co nie jest klientami Crédit Coop, ale możemy być w stanie ich przyciagnąc" (Ibidem).

W przypadku Arizuka, platformy dedykowanej „ekonomii społecznej”, od roku 2014 realizowana jest współpraca z Crédit Coopératif. Dzięki temu partnerstwu bank kontynuuje prowadzoną od kilku lat politykę innowacyjności związaną z crowdfundingiem, zaś dla Arizuka, pozyskiwanie funduszy umożliwia dalszy rozwój. Jak komentuje to Fabrice Carrega, dyrektor generalny i współzałożyciel platformy, „witamy Crédit Coopératif jako inwestora. Z nim dzielimy silne wartości i zainteresowanie innowacjami" (dane: recma.org).

Jednakże, jak wskazuje Stéphanie Savel, prezes WiSeed, „banki sa bardzo ostrożne w angażowaniu się w crowdfunding, zwłaszcza jego model akcyjny" (Chaptal, 2015). Analizując aktualny stan crowdfundingu bankowego we Francji należy stwierdzić, że udział systemów equity-based jest wciąż śladowy, a dominują platformy pożyczkowe.

Zaangażowanie banków w finansowanie społecznościowe wynika niejednokrotnie ze strategii społecznej odpowiedzialności biznesu (CSR). Przykładowo, Crédit Coopératif, Crédit Municipal de Paris, Crédit Mutuel ARKEA, czy Société Générale finansują projekty o silnym wpływie społecznym, kulturowym lub środowiskowym, udzielając np. pożyczek po obniżonych stawkach (Cieply \& Nadant, 2016: 267). Z drugiej strony, banki też korzystają z własnych platform crowdfundingu (Ibidem: 268).

\section{CROWDFUNDING W BANKACH FRANCUSKICH - WYNIKI BADAŃ}

Banque Postale (z Groupe La Poste) od 2017r. stał się właścicielem (Rosca, 2017) platformy KissKissBankBank (KKBB), wykupując jej $100 \%$ akcji. Ta transakcja obejmowała też m.in. marki Hellomerci i Lendopolis. Warto nadmienić, że platforma KKBB już od dłuższego czasu współpracowała z Banque Postale. A mianowicie (Matarin, 2017): w latach 2009 i 2012 XAnge Private Equity (spółka zależna banku) łączną kwotą ok. 2 mln euro dofinansowała platformę, zaś Bank stale wspierał finansowo projekty prezentowane na KissKissBankBank.

Obecne statystyki KKBB (kisskissbankbank.com) są następujące: zgromadzono 149090536 euro na realizację 25287 projektów, ze wskaźnikiem sukcesu 72\%. Jednakże platformę wdrożono w roku 2009, a bank przejął ją dopiero w 2017 roku. Dokonano zatem oszacowania zagregowanych środków finansowych od 2017r, dysponując (Ibidem) cząstkowymi statystykami platformy z lat ubiegłych. Można zatem przyjąć, że w ramach struktury Banku Pocztowego platforma pozyskała kwotę co najmniej $80 \mathrm{mln} €$.

Tabela 1: Statystyki platform crowdfundingu Banque Postale (Groupe La Poste)

\begin{tabular}{lll}
\hline Lp. & Wyszczególnienie & Zagregowane środki finansowe (w $\boldsymbol{€})$ \\
\hline 1. & Lendopolis.com (P) & $\left(^{*}\right) 135000000$ \\
\hline 2. & KissKissBankBank.com (S) & $\left(^{*}\right) 80000000$ \\
\hline 3. & microDon.org (D) & $\left(^{*}\right) 27000000$ \\
\hline 4. & Hellomerci.com (P) & $\left(^{*}\right) 7000000$ \\
\hline 5. & Goodeed.com (D) & $\left(^{*}\right) 5000000$ \\
\hline
\end{tabular}




\begin{tabular}{lll}
\hline 6. & MaFrenchBank.fr & b.d. \\
\hline 7. & Łącznie: & $\mathbf{2 5 4 0 0 0 0 0 0}$ \\
\hline
\end{tabular}

Źródło: opracowanie własne z wykorzystaniem danych Banque Postale.

modele crowdfundingu: S sponsorski; P pożyczkowy; D donacyjny; (*) szacunki własne; b.d. brak danych.

Zakładając określony udział procentowy (według zadanego przedziału czasowego), wyznaczono z kolei kwotę zgromadzonych środków finansowych na platformie Hellomerci (funkcjonującej od 2014r.), na co najmniej 7 mln euro. Analogiczną metodę szacowania przyjęto wobec systemu Lendopolis (lendopolis.com/), wdrożonego w 2014r. bazowano tu na cząstkowych statystykach platformy publikowanych w kolejnych latach. Grupa KissKissBankBank \& Co obejmuje również dwie inne platformy: Goodeed (goodeed.com), wdrożoną w 2014r. oraz microDon (microdon.org) funkcjonującą od 2009r. Dokonano zatem dla w./wym. platform szacunków kwoty pozyskanych środków finansowych od roku 2017 (zob. tabela 1).

W grupie La Poste funkcjonuje też system Ma French Bank (mafrenchbank.fr), wdrożony w 2019r. Jest tzw. neobankiem, którego usługi crowdfundingu są dostępne poprzez smartfon. Zidentyfikowano też współpracę La Banque Postale z WeShareBonds. Bank nabył 10\% udziałów w platformie specjalizującej się w udzielaniu pożyczek dla MŚP; według pracy (Wajsbrot, 2016), platforma będzie mogła w ten sposób inwestować w firmy, których bank sam nie finansuje; i odwrotnie - platforma będzie mogła kierować klientów do Banque Postale; trzecia opcja - mogą być również proponowane wspólne oferty finansowania obligacji i kredytu bankowego.

Inna grupa bankowa - BPCE - jest jedną z większych we Francji, gromadzi 12 banków. Oferuje dostęp do kilku różnych platform crowdfundingu (zob. tabela 2). Przykładowo, Tudigo.co jest platformą według modelu sponsorskiego wykorzystywaną (od 2017r.) przez Banque Populaire Rives de Paris; finalnie pozyskano tu ponad 53 mln EUR. Statystyk nie udostępnia Ma Belle Tribu, skierowana do stowarzyszeń, które realizują inicjatywy solidarnościowe i obywatelskie. Proximea to platforma regionalna Banque Populaire, w tym m.in. Banque Populaire Atlantique, bazująca na modelu inwestycyjno-akcyjnym na rynku nieruchomości; wdrożono ją w roku 2015. Na witrynie proximea.net opublikowano 18 sfinalizowanych projektów - jeśli zagregujemy ich wartości, uzyskamy kwotę co najmniej 12710912 euro; platforma jest dziś nieaktywną.

Tabela 2: Systemy crowdfundingu Banque Populaire (Groupe BPCE)

\begin{tabular}{|c|c|c|c|}
\hline Lp. & & $\begin{array}{l}\text { Platforma (model } \\
\text { funkcjonowania) }\end{array}$ & $\begin{array}{l}\text { Zagregowane } \\
\text { finansowe }(w €)\end{array}$ \\
\hline 1. & Banque Populaire Rives de Paris & Tudigo.co $(\mathrm{S})$ & 53318060 \\
\hline 2. & Groupe BPCE & MyCapital.immo (IA) & (*) 12834000 \\
\hline 3. & Banque Populaire & Proximea.net (IA) & (*) 12710912 \\
\hline 4. & Banque Populaire Auvergne Rhone Alpes & Kocoriko.fr (S) & 1820480 \\
\hline 5. & La Caisse d’Epargne Bretagne Pays de Loire & EspaceDons.com (D) & b.d. \\
\hline 6. & Casden Banque Populaire & Ma Belle Tribu (D) & b.d. \\
\hline 7. & Łącznie & 80683452 & \\
\hline
\end{tabular}

Źródło: opracowanie własne z wykorzystaniem danych grupy bankowej;

modele crowdfundingu: D donacyjny bez nagradzania; S sponsorski; IA inwestycyjny akcyjny; (*) agregacja własna wartości projektów; b.d. brak danych.

Natomiast Kocoriko (kocoriko.fr) to własna platforma donacyjna Banque Populaire Auvergne Rhone Alpes, wdrożona w 2018 roku, w 100\% poświęcona projektom alpejskim. Jak wyjaśnia Pascal Marchetti, dyrektor generalny Banque Populaire des Alpes, wdrażając Kocoriko, „chcieliśmy zmobilizować energię naszych pracowników wokót projektu opartego na wartościach wspótpracy” - i - „dać szansę lokalnym projektom, które otrzymuja niewielkie finansowanie tradycyjnymi kanałami" (Kocoriko, 2018) - bank dofinansowuje projekty, maksymalnie w kwocie $1500 €$.

Grupa BPCE oferuje też inne systemy crowdfundingu, bądź współpracę z nimi: MyCapital.immo (system inwestycyjnyakcyjny, wykupiony w roku 2017 przez BPCE), czy Espace Dons - system donacyjny La Caisse d’Epargne, funkcjonujący od roku 2015. Bank SOCFIM (spółka zależna BPCE) współpracuje z Fundimmo (fundimmo.com), BRED Banque Populaire realizuje współpracę z platformą „Club funding” (clubfunding.fr), zaś EasyCrowd.net (donacyjna platforma white-label) jest w partnerskich relacjach z Banque Populaire Auvergne Rhone Alpes oraz Casden Banque Populaire.

Spośród innych przedsięwzięć banków francuskich wymieniam następujące. BNP Paribas (Dziuba, 2021a) dokonał implementacji systemu crowdfundingu SmartAngels.fr (2016r.); przedsiębiorstwa mogły tu dokonywać emisji papierów wartościowych (mini-bonds), poprzez model blockchain; platforma jest dziś archiwalną. Ze SmartAngels współpracował m.in. internetowy bank Fortuneo (www.fortuneo.fr/). Société Générale współpracuje m.in. z indonezyjską platformą pożyczkową Alami (dane www.techinasia.com), jak i z systemem invoice finance Aztec Money (The Papers, 2015). Bank też w 2018r. wykupił akcje platformy Lumo, funkcjonującej od 2012r, stając się jej właścicielem; Lumo specjalizuje się w projektach transformacji energetycznej, tj. produkcji energii elektrycznej ze źródeł odnawialnych. 
Według danych systemowych (lymo.fr), dotąd zgromadzono kwotę 31495500 euro, na realizację 24958 projektów. Można zatem przyjąc, ${ }^{\text {iii }}$ że w ramach struktury Société Générale, Lumo pozyskało zagregowaną kwotę ok. 25 mln $€$.

Bank spółdzielczy Crédit Mutuel (creditmutuel.fr) również udostępnia usługi crowdfundingu: grupa Crédit Mutuel Arkéa (Arkéa Banque E\&I) współpracuje z platformą Koregraf inwestowania na rynku nieruchomości; bank też jest w relacjach partnerskich z platformami Younited Credit (Prét d 'Union) i Credit.fr; z systemem Younited Credit współpracuje bank inwestycyjny BPIfrance (Weeks, 2017). Crédit Mutuel współpracuje również z platformą Hello Asso (helloasso.com/). W przypadku Groupama Banque - bank udziela pożyczek francuskim firmom za pośrednictwem platformy Unilend. Zidentyfikowano też współpracę Orange Bank (uprzednio: Groupama Banque) z systemem pożyczkowym Unilend (funkcjonował w latach 2013-2018), jak również współpracę Société Générale z platformami SPEAR, Arizuka, czy mikro-kredytów Babyloan. Neobank Ethiko (ethiko.fr) udostępnia usługi crowdfunfingu dla społeczmości muzułmańskiej. Natomiast „Tous Acteurs” to platforma crowdfundingu charytatywnego w banku Crédit Agricole (des Savoie). Regionalny bank Crédit Agricole Nord Midi-Pyrénées współpracuje z platformą MiiMosa, dedykowaną rolnictwu i produkcji żywności. Francuski neobank Qonto jest w relacjach partnerskich z włoską platformą BorsadelCredito (Jiménez, 2019). Z kolei w Crédit Agricole dokonano wdrożenia platformy pożyczkowej FriendsClear (obecnie już archiwalnej); była to zapewne pierwsza implementacja crowdfundingu w banku w skali świata.

Wielość relacji cechuje banki BNP Paribas i Crédit Coopératif. BNP Paribas, oprócz w./wym. implementacji SmartAngels.fr, współpracuje z platformą donacyjną Ulule, jak i holenderskim systemem pożyczkowym Dynamic Credit Group, wykupując większość jego udziałów (dane www.creditflux.com); jest też strategicznym partnerem systemu mikro-kredytów GrameenAmerica.org (dane: group.bnpparibas). Natomiast BNP Paribas AM z brytyjskimi platformami pożyczkowymi CODE Investing (Lanyon, 2018) i Caple.com (Lanyon, 2021), także z Swoop Funding (Lloyd, 2021). Crédit Coopératif jest inicjatorem implementacji platformy Agir \& Co (w 2015 roku), funkcjonującej według modelu sponsorskiego. Ponadto bank realizował współpracę z systemami Babyloan, Arizuka, Spear, WiSeed, Tudigo.co, jak i Afexios (dziś archiwalnej), także EasyCrowd.net.

Reasumując, w bankach francuskich pozyskano poprzez platformy crowdfundingu zagregowaną kwotę co najmniej 359.7 milionów $€$. Systemy crowdfundingu bazują na różnych modelach funkcjonowania, najczęściej donacyjnych z nagradzaniem, także pożyczkowych; spotyka się niemal dowolne modele funkcjonowania, także mikro-kredytów, charytatywne, czy inwestycyjne akcyjne. Zidentyfikowano najmniej 51 przedsięwzięć banków (wdrożenia własnych platform, wykorzystywania systemów zewnętrznych, czy tworzenia relacji partnerskich z platformami, w tym w ramach strategii corporate social responsibility), choć kilka z nich ma już charakter archiwalny.

\section{SYSTEMY CROWDFUNDINGU W BANKACH SZWAJCARII - WYNIKI BADAŃ}

Przeprowadzone analizy wykazały, że grupy szwajcarskich banków kantonalnych wykorzystują dwie platformy crowdfundingu: WeMakeIt.ch i Funders.ch. WeMakeIt to system donacyjny z nagradzaniem (tj. sponsorski) dla realizacji projektów kreatywnych, stosowany nie tylko w Szwajcarii, ale i w Niemczech, Austrii oraz we Włoszech. Współpracuje z kilkoma bankami szwajcarskimi, m.in.: St. Galler Kantonalbank, Basler Kantonalbank (BLKB), Urner Kantonalbank (UKB) i Zūrcher Kantonalbank (ZKB), Bank SLM AG. Platforma banku SLM AG (avanti.wemakeit.ch) funkcjonuje od 2012 roku, przy czym w bankach wdrażano ją dopiero od roku 2016. Tabela 3 zestawia statystyki dla tych banków. Najmniejsze kwoty zgromadzono w Urner i Zūrcher Kantonalbank, gdzie najpóźniej wdrożono platformę. Jak wykazano, w bankach wykorzystujących analizowaną platformę pozyskano zagregowaną kwotę ponad 2.1 miliona CHF, tj. 2.023 miliona euro ${ }^{\text {iv }}$. WeMekeIt podaje, że łącznie za jej pośrednictwem zgromadzono 65.7 miliona CHF na realizację 5489 projektów, ze wskaźnikiem sukcesu $62 \%$. Jednakże te dane dotyczą wszystkich zastosowań WeMakeIt, nie tylko w bankach, ale $\mathrm{i}$ w innych podmiotach.

Tabela 3: Statystyki WeMakeIt w bankach kantonalnych

\begin{tabular}{|c|c|c|c|c|}
\hline \multirow[t]{2}{*}{ Lp. } & \multirow[t]{2}{*}{ Wyszczególnienie } & \multirow{2}{*}{$\begin{array}{l}\text { Zagregowana } \\
\text { zgromadzonych } \\
\text { CHF) }\end{array}$} & wartość & \multirow{2}{*}{$\begin{array}{ll}\text { Liczba } & \text { sfinalizowanych } \\
\text { projektów }\end{array}$} \\
\hline & & & środków (w & \\
\hline 1. & Basler Kantonalbank & $(*) \sim 1500000$ & & 61 \\
\hline 2. & St. Galler Kantonalbank & (*) 241701 & & $(*) 10$ \\
\hline 3. & Bank SLM AG & (*) 176367 & & $(*) 9$ \\
\hline 4. & Zūrcher Kantonalbank & (*) 114289 & & (*) 1 \\
\hline 5. & Urner Kantonalbank & (*) 96790 & & (*) 4 \\
\hline 6. & Łącznie & 2129147 & & 85 \\
\hline
\end{tabular}

Źródło: Agregacja własna statystyk banków kantonalnych.

(*) agregacja własna; b.d. brak danych.

Z kolei system Funders.ch jest platformą crowdfundingu w Luzerner Kantonalbank (LUKB), wdrożoną w 2016 r. W kolejnych latach, na podstawie umów partnerskich z LUKB, implementacji dokonano w kilku innych bankach kantonalnych: Obwaldner Kantonalbank, Berner Kantonalbank, Thurgauer Kantonalbank i Nidwaldner Kantonalbank. Funders funkcjonuje zarówno według modelu sponsorskiego, jak i pożyczkowego. Aktualne statystyki dla poszczególnych banków nie są publikowane, ale dostępne są dane łączne (dane: funders.ch): na realizację 280 projektów 
(ze wskaźnikiem sukcesu 74\%) pozyskano zagregowaną kwotę 7701618 CHF, tj. 7.317 miliona euro. Można przypuszczać, że gros tych środków zgromadzono w Luzerner Kantonalbank.

W roku 2014 Raiffeisenbank Niederhelfensch jako pierwszy szwajcarski bank uruchomił platformę crowdfundingu „Gemeinsam-unterwegs.ch”. Inne banki należące do grupy szybko znalazły w tym pomyśle innowacyjne rozwiązanie. W rezultacie, rok później, dla całej grupy bankowej powstała nowa platforma: „Lokalhelden.ch”, bazująca na modelu charytatywnym. Lokalhelden to inicjatywa „Zaangażowany w Szwajcarię” (Engagiert für die Schweiz) Grupy Raiffeisen, do realizacji regionalnych (lokalnych) projektów.

Bank współfinansuje projekty. Na platformie Lokalhelden (raiffeisen.ch):

- pula dotacji na darowizny obejmuje kwotę $6000 \mathrm{CHF}$ rocznie;

- maksymalnie $2000 \mathrm{CHF}$ z tej puli jest rozdzielane na projekt;

- darowizna jest podwajana do maksymalnej kwoty $50 \mathrm{CHF}$ na osobę wspierającą; np. w przypadku darowizny w wysokości 50 CHF kwota jest podwajana do 100 CHF, zaś dla darowizny w wysokości 400 CHF dodawana jest zryczałtowana stawka $50 \mathrm{CHF}$;

- gdy tylko projekt zakończy się sukcesem, nie ma dodatkowego wsparcia z puli darowizn.

$\mathrm{Na}$ witrynie Lokalhelden.ch publikowane są wszystkie realizowane projekty (tj. ufundowane, nie sfinalizowane i te, których kampanie wciąż trwają). Zestawiono również zbiorcze statystyki: ufundowano 1676 projektów ze wskaźnikiem sukcesu 81\% i zgromadzono zagregowaną kwotę 28881106 CHF, tj. 27.437 miliona $€$.

Grupa Raiffeisen Schweiz obejmuje 245 banków (Liste, 2021). Obecnie każdy z tych banków ma dostęp do platformy Lokalhelden.ch. Każdy publikuje wykaz realizowanych lokalnie projektów. Przykładowovo w Banca Raiffeisen Colline del Coresio pozyskano kwotę co najmniej 45606 CHF, Banca Raiffeisen Centovalli Pedemonte 47910 CHF, Banca Raiffeisen del Moesano 51426 CHF, Banca Raiffeisen del Camoghe 2570 CHF, zaś w Banca Raiffeisen Basso Coresio 0 CHF (są tu liczne trwające kampanie crowdfundingu, żadnej jeszcze nie ukończono). Takie agregacje można przeprowadzić dla każdego z banków Gruppe Raiffeisen Schweiz.

Wdrażane są w Szwajcarii również inne platformy crowdfundingu, także według innych modeli biznesowych (nie udostępniają one jednak statystyk):

- Bank Raiffeisen Lausanne-Haute-Broye-Joral współpracuje z platformą Foxstone, dokonującą inwestowania na rynku nieruchomości (foxstone.ch), zaś Banque Raiffeisen Nyon-La Vallée realizuje wspólpracę z systemem Investers (investers.ch), inwestycyjnym real-estate;

- Basellandschaftliche Kantonalbank (BLKB) wdrożył platformę pożyczkową Miteinander-erfolgreich.ch; implementacji dokonano w 2014 roku, we współpracy z dostawcą usług telekomunikacyjnych Swisscom; platforma już nie funkcjonuje, ma charakter archiwalny;

- Bank BLKB również współpracuje z platformą invoice trading Advanon (advanon.cg24.com);

- Alternative Bank Schweiz AG (abs.ch) wspiera projekty socjalne i ekologiczne na platformie 100-days.net (obecnie pod nazwą: Crowdify.net);

- Neobank Neon (neon-free.ch) oferuje system inwestycyjny akcyjny;

- Bank UBS Schweiz (ubs.com/) wdrożył platformę inwestowania w nieruchomości key4;

- według danych Credit Suisse, Bank współpracuje z Prosper.com, a także z platformą mikro-kredytów Opportunity.org, realizując strategię społecznej odpowiedzialności biznesu;

- Migros Bank współpracuje z systemem pożyczkowym Credaris.ch (dane: punkt4.info);

- UBP (Union Bancaire Privée) nawiązał współpracę z globalną platformą LendingClub.

Mobilny bank BCN, Banque Cantonale Neuchateloise (www.bcn.ch), udostępnia usługi platformy „Yes We Farm”, dedykowanej rolnictwu i produkcji żywności; według danych systemowych (yeswefarm.ch/), pozyskano kwotę 1668 959 CHF, tj. 1.586 miliona EUR. Jednakże prawdziwym ,gigantem” w segmencie crowdfundingu bankowego jest platforma pożyczkowa Cosmofunding (cosmofunding.com), wdrożona w 2018 r. przez grupę bankową Vontobel. Według danych (Amrein, Dietrich, 2021: 25), w 2020 roku wartość udzielonych pożyczek wyniosła aż 4.3 miliarda CHF (tj. 4.042 miliarda euro); rok wcześniej średnia pożyczka to 32.8 miliona CHF, a pożyczki realizowano w zakresie od 700 tys. do 100 mln CHF.

W bankach szwajcarskich dominują systemy crowdfundingu donacyjnego (zarówno bez nagradzania - charytatywne, jak i z nagradzaniem - sponsorskie) i hybrydowego. W badanym okresie pozyskały łącznie zagregowaną kwotę ponad 4080.383 milionów euro. Zidentyfikowano 25 przedsięwzięć crowdfundingu bankowego (wdrażanie własnych platform, wykorzystywanie systemów zewnętrznych), a biorąc pod uwagę dostęp banków całej grupy Raiffeisen - 269 przedsięwzięć. 


\section{PODSUMOWANIE. PERSPEKTYWY DALSZYCH BADAŃ}

Przeprowadzone badania pozwoliły zidentyfikować liczne przedsięwzięcia crowdfundingu w bankach francuskich i szwajcarskich, poprzez które łącznie pozyskano zagregowaną kwotę co najmniej 4.4 miliarda euro. Rzeczywiste rozmiary analizowanego sub-segmentu rynkowego są jednak większe, gdyż wiele z badanych systemów nie udostępnia statystyk. Kolejne badania poświęcone zostaną crowdfundingowi w pozostałych bankach europejskich, co pozwoli oszacować wielkość analizowanego segmentu rynkowego na kontynencie Europy.

Reasumując rozważania, w praktyce obserwuje się szereg strategii (modeli biznesowych) banków w ramach koncepcji crowdfundingu. W tym artykule skoncentrowano się na modelach reprezentowanych przez banki francuskie i szwajcarskie. Najważniejsze modele to wykorzystywanie własnej platformy crowdfundingu do realizacji projektów (typowym przykładem jest Banque Populaire Auvergne Rhone Alpes z implementacją Kocoriko.fr, także Basellandschaftliche Kantonalbank ze wdrożeniem platformy Miteinander-erfolgreich.ch), a z drugiej strony fundowanie własnych projektów na zewnętrznych platformach, np. Banque Postale bazuje na systemie KissKissBankBank. Inny model reprezentuje platforma Spear - gromadzi fundusze od osób fizycznych, a następnie powierza je bankowi (Société Générale), który z kolei udziela pożyczek, ponosząc przy tym określone ryzyko. Banki współpracują też z platformami crowdfundingu w zakresie realizacji strategii społecznej odpowiedzialności biznesu; przykładowo, BNP Paribas sponsoruje projekty na zewnętrznej platformie Ulule, współpracując też z Wiseed. Metoda crowdfundingu implementowana jest zarówno w bankach ,tradycyjnych”, jak i mobilnych (neobankach). Wdrażane są systemy w technologii blockchain, np. SmartAngels.fr w BNP Paribas Group. Banki „stają się” też (Dziuba, 2021b) właścicielami zewnętrznych platform crowdfundingu, dokonując ich wykupu. Nie jest to ostateczna lista modeli ${ }^{\mathrm{vi}}$. Problematyka ta wymaga dalszych badań i studiów.

\section{LITERATURA}

1. Agrawal, A., Catalini Ch. \& Goldfarb A. (2011). The Geogra phy of Crowdfunding, The National Bureau of Economic Research (NBER). NBER Working Paper, No. 16820.

2. Agrawal, A., Catalini Ch. \& Goldfarb A. (2013). Some Simple Economics of Crowdfunding. The National Bureau of Economic Research. NBER Working Paper, No. 19133.

3. Agrawal, A., Catalini Ch. \& Goldfarb A. (2013). Crowdfunding: Social Frictions in the Flat World?. University of Toronto, NBER Working Paper, 14 October.

4. Agrawal, A., Catalini, C. \& Goldfarb, A. (2015). Crowdfunding: Geography, Social Networks, and the Timing of Investment Decisions. Journal of Economics \& Management Strategy, 24, pp. 253-274. http://dx.doi.org/10.1111/jems.12093.

5. Amrein, S. \& Dietrich, A. (2021). Marketplace Lending Report Switzerland 2021. Lucerne University of Applied Sciences and Arts Hochschule Luzern, TMF Group, SMLA (Swiss Marketplace Lending Association), Institute of Financial Zug IFZ.

6. Belleflamme, P., Lambert, T. \& Schwienbacher, A. (2013). Individual Crowd-funding Practices. Venture Capital, 15(4), doi: 10.2139/ssrn.2151179.

7. Belleflamme, P., Lambert, T. \& Schwienbacher, A. (2014). Crowdfunding: Tapping the Right Crowd. Journal of Business Venturing, No. 29(5), pp. 585-609.

8. Brown, R., Mawson, S., Rowe, A. \& Mason, C. (2015). Harnessing the Crowd: The Demand-Side Dynamics of Equity Crowdfunding in Nascent Entrepreneurial Ventures. Working Paper in Responsible Banking \& Finance (RBF), University of St. Andrews, School of Management, WP No. 15-009.

9. Burkett, E. (2011). A Crowdfunding Exemption? Online Investment Crowdfunding and U.S. Securities Regulation, Transactions: The Tennessee Journal of Business Law, Vol. 13, Issue 1, pp. 63-104.

10. Chaptal, S. (2015). Crowdfunding: vers une collaboration mesurée entre banques et plates-formes?. „Revue Banque", www.revue-banque.fr/.

11. Cieply, S. \& Nadant, Le A.-L. (2016). Le crowdfunding: modele alternatif de financement ou generalisation du modele de marche pour les start-up et les PME?. Revue d Economie Financiere, 2016/2 No. 122, pp. $255-272$.

12. Danmayr, F. (2014). Archetypes of Crowdfunding Platforms. A Multidimensional Comparison. Springer Gabler.

13. Dresler, S., eds. (2014). Crowdfunding, a Guide to Raising Capital on the Internet. John Wiley \& Sons Inc., Hoboken, New Jersey.

14. Dziuba, D.T. (2021a). Initiatives for the Implementation of Regional Crowdfunding Systems in the Financial Group of German Savings and Volks- Raiffeisen Banks. Humanities and Social Sciences Reviews, 2021, Vol 9, No 4, pp. 24-32, https://doi.org/10.18510/hssr.2021.945.

15. Dziuba, D.T. (2021b). Crowdfunding korporacyjny. Difin, Warszawa.

16. Humphries, B. (2010). Funding the Future: Marketplace Lending Equity Crowdfunding, and Bank Lending. North Carolina Banking Institute, UNC School of Law, Discussion Paper, Volume 24, Issue 1.

17. Jenik, I., Lyman, T. \& Nava, A. (2017). Crowdfunding and Financial Inclusion. CGAP Working Paper, Marngtonch, CGAP.org, Washington, DC.

18. Jiménez, E. (2019). BorsadelCredito.it teams up with French neobank Qonto to suport SMEs in Italy. International Investment, November 14, https://www.internationalinvestment.net/.

19. Kocoriko (2018). Nouveau: Kocoriko réveille les Alpes!, Communiquéde presse. Banque Populaire des Alpes, http://www.grenoble-ecobiz.biz/. 
20. Lanyon, D. (2021). Shawbrook Bank and Caple launch strategic partnership. Altfi, March 10, https://www.altfi.com/.

21. Lanyon, D. (2018). Challenger bank partners with P2P lender to double loan portfolio. Altfi, November 12 , https://www.altfi.com/.

22. Liste (2021) Liste der Raiffeisenbanken in der Schweiz. Wikipedia, https://de.wikipedia.org/.

23. Lloyd, M. (2021). Swoop Funding partners with BNP Paricas to offer unsecured loans for SMEs. Peer2Peer Finance News, June 23, https://www.p2pfinancenews.co.uk/.

24. Matarin, Y. (2017). Pourquoi La Banque Postale et KissKissBankBank se marient. Capital, 28 Juni, https://www.capital.fr/.

25. McCarthy, A. (2017). The future of finance is Crowd-Banking, https://techbulion.com/.

26. Mollick, E.R. (2012). The Dynamics of Crowdfunding: Determinants of Success and Failure. The Wharton School of the University of Pennsylvania; SSRN, http://ssrn.com/abstract=2088298.

27. Mollick, E. R. (2013). Swept Away by the Crowd? Crowdfunding, Venture Capital, and the Selection of Entrepreneurs. University of Pennsylvania - Wharton School; SSRN, http://ssrn.com/abstract=2239204.

28. Mollick, E.R. (2014). The Dynamics of Crowdfunding: An Exploratory Study. Journal of Business Venturing, 1 (29): 1-16.

29. Mollick, E.R. (2016). The Unique Value of Crowdfunding Is Not Money - It`s Community. Harvard Business Review, April 21.

30. The Papers (2015). Société Générale, Goldman Sachs eye peer-to-peer lending push, https://thepapers.com/.

31. Rich, J.R. (2014). The Crowd Funding Services Handbook. Raising the Money You Need to Fund Your Business, Project, or Invention. John Wiley \& Sons Inc., Hoboken, New Jersey.

32. Rosca, M. (2017). Banque Postale acquires crowdfunding website KissKissBankBank. S\&P Global, June 28, https://www.spglobal.com/.

33. Wajsbrot, S. (2016). La Banque Postale se lance dans le `crowdlending`aux PME. Les Echos, October 24 , https://www.lesechos.fr/.

34. Weeks, R. (2017). French marketplace lender Younited Credit raises 40m euro for European expansion. Altfi, September 19, https://www.altfi.com/.

\section{PRZYPISY}

\footnotetext{
${ }^{\mathrm{i}}$ Takie platformy pożyczkowe określane są skrótem LaaS (Lending-as-a-Service).

${ }^{\text {ii }}$ Wypowiedź Benoit Bazzocchi, prezesa Smart Angels. Zob. (Chaptal, 2015).

${ }^{\text {iii }} \mathrm{W}$ oszacowaniu brano m.in. pod uwagę dynamikę gromadzenia funduszy.

${ }^{\text {iv }}$ Według kursu; $1 \mathrm{CHF}=0.95$ EUR.

${ }^{\mathrm{v}}$ Wyliczenia własne, na podstawie agregacji wartości projektów.

${ }^{\mathrm{vi}} \mathrm{W}$ autorskiej pracy (Dziuba, 2021a) zidentyfikowano też inne modele, charakterystyczne dla innych krajów europejskich i USA.
} 